\title{
The Comparative Effect of Student Team-Achievement Division and Cooperative Integrated Reading and Composition on EFL Learners' Speaking Complexity
}

\author{
Zeinab Ghasemi ${ }^{1}$, Abdollah Baradaran ${ }^{2}$ \\ ${ }^{1}$ College of Foreign Languages and Literature, Central Tehran Branch, IAUCTB, Tehran, Iran \\ ${ }^{2}$ Department of Engl ish, Central Tehran Branch, IAUCTB, Tehran, Iran
}

Corresponding Author: Zeinab Ghasemi, E-mail: ghasemi21zeinab@gmail.com

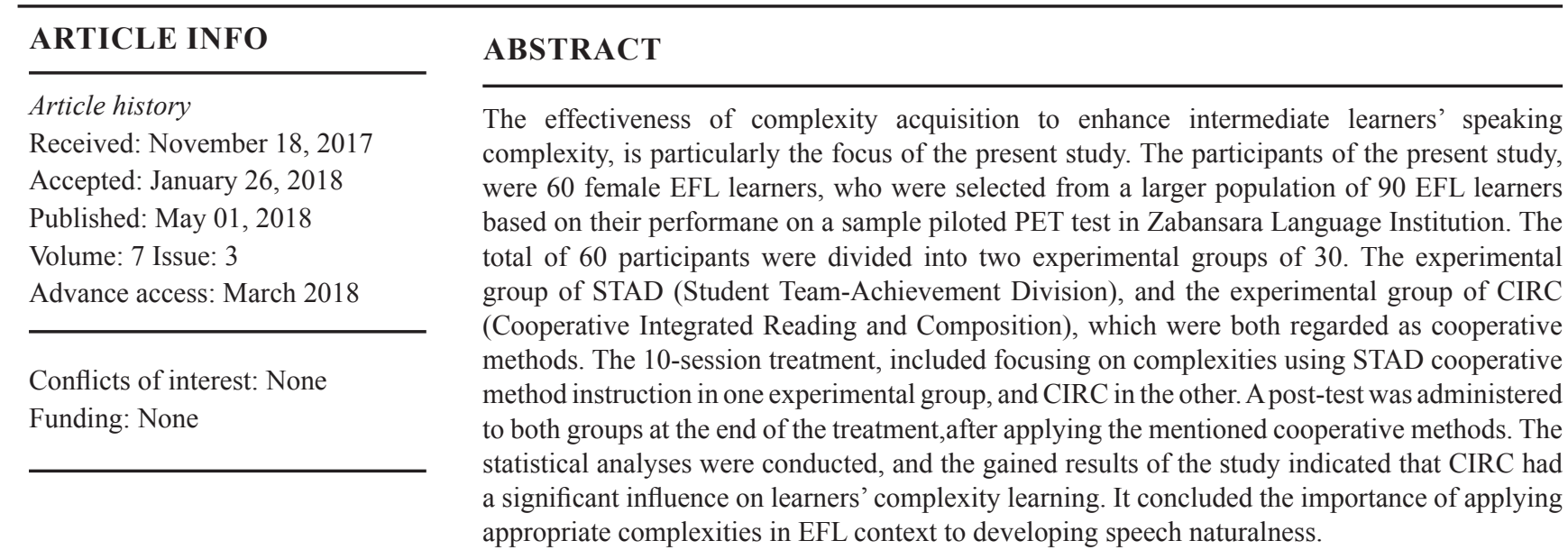

Key words: Student Team-Achievement Division (Stad), Cooperative Integrated Reading and Composition (Circ), Speaking Complexity, Cooperative Learning (Cl), Efl Learner

\section{INTRODUCTION}

Speaking as the real means of communication, includes variety of factors such as colloquial language, performance variables, reduced forms, redundancy clusters, rate of delivery, stress, rhythm and intonation (Brown, 2001). According to Richards (2008), as language learners move from lower-intremediate to upper-intermediate and advanced level, there is not only a need to equip students with sufficient grammar knowledge, vocabulary, accuracy and fluency, but also the characteristics of natural speech. Therefore, there is a need to motivate learners to produce word combinations and native-like structures by recalling high-frequency complexities, which lead to communication, as the real definition of language learning. Moreover, the present educational culture in Iran, is to some extent based on individualistic and competetive learning style, which observes the role of teacher as a great authority, who projects learners' development, rather than being a moderator (Rashidi \& Najafi, 2010).

Generally, the used method in the context of an English class, with specific accentuation on naturalness and cooperation, takes a vital role. Historically, the world of language teaching, however has witnessed different methods and models, the one, which has attracted considerable attention and become popular among language teachers and learners, is Cooperative Learning (CL). Killen (2007) defines it as an instructional design that stimulates peer interaction and learner-to-learner cooperation in the process of fostering successful learning by all. The findings (e.g. Kagan, 1986; Johnson \& Johnson, 1985) show that through a good utilization of $\mathrm{CL}$, positive learning attitude, improvement in thinking skills, improvement in interaction skills and enhancement in learning achievements can all be achieved. Two subcategories of CL can be named as:

1. Student Team-Achievement Division (STAD)

2. Cooperative Integrated Reading and Composition (CIRC)

Student Team-Achievement Division (STAD), refers to a class with heterogeneous performance level, sex, and ethnicity, who are formed in groups of four or five members. The material is presented by the teacher and team-members work together to master the given lesson. Individuals take quizzes regularly and are assigned an improvement score (Arends, 1997).

According to Slavin (2010), Cooperative Integrated Reading and Composition (CIRC), alludes to a program for grade level reading and writing instruction in intermediate grades and beyond. Teachers make use of reading text much as in traditional reading programs. Teams with two pairs from different reading groups in class are formed. The stu- 
dents work as a team to master main ideas and other comprehension skills. In most CIRC activities, the sequence that students follow, is teacher lessons, team practice, team pre-assessments and quizzes. In this way, they do not take the quiz until their teammates have determined that they are ready. Using collaborative tasks based on natural and real-life contexts are viewed as the main purposes of language learning. Classroom participation, group work, role plays, deal with the complex concept of classroom interactional tasks and cooperation(Richards \& Rodgers, 1986).

Consequently, the present study focuses on the age-old problems about a big deficit of complexities and its considerable contribution to the speaking naturalness, moreover individualistic and competetive teaching and learning methods are criticized to convince and encourage students to learn in groups and as a result of interaction by applying two well-known cooperative methods for the purpose of leading the community of students to cooperation and teamwork.

\section{REVIEW OF LITERATURE}

\section{Speaking Complexity}

Speaking as one of four language skills, consists of some sets of tasks in order to come up with a satisfactory result. It is used for many purposes, for example a casual conversation, social contact, discussion over a topic, expressing and sharing ideas (Richards \& Renandy,2002). Speaking is observed as a type of productive aural/oral skill, which consists of different producing systematic verbal utterances to convey meaning. However, individual words have always been interpreted as vocabulary, it is evident that much of lexis is formed by sequence of words, which act as individual units, with meanings that differ from separate words. According to Wray (2002), a continuous or discontinuous sequence of words, which appears to be prefabricated, is seen as complexity. These forms are stored and retrieved whole from memory at the time of use. Interest in spoken performance has developed a considerable number of research studies on complexities, used in learners' productions. According to commentary on speaking fluency, complexity of speaking task and familiarity of the subject as well, have an important role in speakers' ability (Pawley \& Syder, 1983). Complexities among speakers' productions have various elements and the usage of complexities increase the expected naturalness of learners' utterances. In general, multi-word units as complexities are mentioned in a high number of research studies. The terminologies differ from study to study as formulas and lexical phrases, bundles and pre formulated language. Following the definitions used by O'Keeffee, McCarthy and Carter (2007), complexity refers to the natural samples produced by learners, which are sometimes recognized as intact phrases and are sometimes strings of words commonly found together. Research studies show that $80 \%$ of the discourse components are varieties of lexical complexities, instead of individual words (Altenberg, 1998). Hence, a large proportion of any discourse, is based on complexities, and if a language learner, could active a large number of complexi- ties, it would be really helpful to them. Lexical complexities conventionally fall into the following categories:

- $\quad$ Playwords (e.g. by mean of, in this way)

- Collocations, or word partnerships (e.g., come to life, be fully justified)

- Institutionalized utterances (e.g., It's beyond me; if not for ...)

- $\quad$ Sentence frames and heads (e.g., Some believe that..., others hold that ...)

- Event text frames (e.g., In this paper we eplore.,Firstly..;Secondly...;Finally...)

The process of learning and retrieving chunks and complexities is formed by some procedures:

- Recognizing Chunks and Cultivating Awareness of Complexities

- $\quad$ Practicing and Analyzing Chunks and Complexities

- Consolidating the mastering of chunks and complexities

While most speech production studies have shown the importance of complexities, mastering and acquisition of them, for the purpose of enhancing learners' proficiency level, via cooperative learning still needs further research studies.

\section{Cooperative Learning}

A common purpose and working to one another, make the main meaning of cooperation. The educational concept of this, is an approach of teaching and learning, which engages classroom members by forming small groups in order to accomplish their goals. There are some definitions of learning which are based on cooperation by prominent scholars. According to Johnson, Johnson and Smith (1991), the cooperation learning (CL), is a small organization work based on interdependence, accountability, group processing and social skills. The preplanned items would be understanding a concept, solving a problem and accomplishing a task. Following the mentioned steps, learners will promote their own and each other's learning. In other words, cooperation is in direct connection with interaction and negotiation among various levels of members, who participate in a variety of tasks by purpose of sharing information. Slavin (1980) describes cooperative learning as students performing in small groups that are given rewards based on the group's presentations. Johnson and Johnson (1999) suggest that "cooperative learning is the instructional use of small groups so that students work together to maximize their own and each other's learning. It may be contrasted with competitive and individualistic learning" (p. 5). Researchers state that cooperative learning prepares learners to act in team (Fiechnter \& Davis, 1991), and persuades students to active engagement in a society (Kagan, 1994). An effective example of communicative language teaching can be named as CL. Putnam (1995) claimed, "The CL is included within a communicative language teaching framework" (p. 67). He pointed out that the CL activities are often used as important factors in the complex field of communicative language teaching. Cooperative learning provides students with a more comfortable and relaxed atmosphere, which leads students to more interactions. The deductions and implications of research studies approve 
that following significant results can be obtained through implementing CL:

- Positive learning attitude

- Interaction skills

- Thinking skills

- Enhancing learning achievement

Slavin (2010) states that, cooperative learning can be divided into many totally different forms, but all of them make students work in small groups or teams to help one another learn academic material. Cooperative learning can help teachers transfer his/her knowledge more successfully as a complementary element. He also reported that, cooperative learning methods fall into two main categories. One set "Structured Team Learning" involves rewards to teams based on the learning progress of their members, and they are also characterized by individual accountability, which means that team success depends on individual learning, not group products. A second set as"Informal Group Learning Methods" that covers methods more focused on social dynamics, projects, and discussion than on mastery of well-specified content. Structured Team Learning Method is made of nine different items, as Student Team Learning, Team Assisted Individualization, Teams-Games-Tournament, Peer-Assisted Learning Strategies, Student Teams-Achievement Divisions, Cooperative Integrated Reading and Composition, Informal Group Learning Methods, Jigsaw and Jigsaw II, and Group Investigation.

\section{Student Teams-Achievement Divisions (STAD)}

Student Team-Achievement Division is a cooperative learning method in which language learners contribute to one another in small heterogeneous groups for diverse subject areas as math, language, arts, social studies and science. The STAD method has consistently been known to be the most effective cooperative learning methods (Adesoji \& Lbraheem, 2009; Khan \& Inamullah, 2011; Sharan, 2014; Tiantong \& Teemuangsai, 2013; Tran, 2014). STAD increases not only collaboration, but also independent learning simultaneously. This is seen as a very applicable method to different levels of learners in heterogeneous groups. Additionally, the aim of STAD is pushing students toward learning in teams and to capitulate that a task would be completed thoroughly if all members understand the content (Slavin, 1994).

\section{Cooperative Integrated Reading and Composition (CIRC):}

Cooperative Integrated Reading and Composition is developed to support "skill-based reading groups" approach. Firstly, reading groups are formed and next, learners are paired off within the groups. When the instructor starts to work with a group of members, couples make effort to teach one another meaningful reading and writing skills. Skill-building activities such as oral reading, contextual guessing, asking questions, summarizing, writing a composition based on the story, revising-correct composition, are all done by students help(Durukan in Academic Journal, 2010, p.2). The effectiveness of interaction techniques in small groups has been investigated by Arthy (2012), and the enhancement of reading comprehension and collaborative attitude among team members are suggested as the relevant results.

\section{METHOD}

\section{Participants}

In order to cope with the research question and provide reasonable answer, the target population of this study was formed by 60 female language learners, classified in intermediate level of English proficiency, according to their textbook (American English File 3) and the ranking criteria of the institute. As it will be explained later in this chapter, after selecting the participants for having access to homogeneous group to attend in this study, PET proficiency test was also used to come up with a homogenous group of learner's level. They were in a range of 14 to 20 and the total number of participants were chosen out of an initial collection of $90 \mathrm{EFL}$ learners, as a result of homogenizing test, at Zabansara institution in Tehran. The two mentioned methods (STAD and CIRC) led us to shape up two samples. 30 language learners were assigned randomly into STAD group and the other 30 learners into CIRC.

\section{Instruments}

The following instruments and materials were applied in this research study, a discription of which follows.

\section{Preliminary English Test (PET)}

A standard version of PET was piloted and administered as the first instrument, in order to measure the participants' general proficiency level. The PET consisting 100 items, was administered to 90 participants to select homogeneous intermediate participants. the mean, median and mode of the PET scores were 68.47, 69, and 63 respectively. These central parameters are not very far from each other showing that the scores are dispersed normally around the mean.

\section{Speaking Post-test(PET)}

In order to determine whether a significant difference was seen between the two groups' mean scores, all the student were supposed to take a speaking test sample of PET. Note that the speaking complexity was measured as the number of used complexities per 100 words (Richards, 2008).

\section{Instructional Materials}

The speaking tasks, which were employed in this study were selected from the following books.

- American English File series(2008), as the participants' course book (Clive Oxenden, Christina Latham-Koenig, and Paul Seligson)

- Select Readings, (Linda Lee and Erik Gundersen), consisting authentic reading passages

- $\quad$ Discovering fiction (O.Henry, William Saroyan, Gwendolyn Brooks, Issac Asimov, and Sandra Cisneros), including. pre-readings and post-reading activities. 


\section{Procedure}

The two mentioned cooperative methods, were applied to 60 homogeneous participants, divided into two categories, as STAD and CIRC, following a PET administration. The first session was assigned as an introductory session for the purpose of getting acquainted and clarifying the objectives of the treatment. There were 6 five-member learning teams, which contained a combination of above, average and low-achievers. Each individual lesson was held in one session ( 2 hours), in total 10 sessions, consisting 20 hours of treatment. In both groups, the learners were all faced with a pre, while and post-task, presented by the instructor to make a natural context, related to the chosen topic. In other words, it gives the participants an opportunity to prepare a natural and authentic environment (Ellis, 2003).

The pre-task phase, gets approximately 30 minutes of the whole time for each session. After the instructor's presentation the students start reading the text silently for the purpose of answering the comprehension questions on the handed text. Follwing this, all the questions are answered and checked by all the participants and the teacher's monitoring. As it is common, the next step is reading aloud by the learners, which is followed by asking the complexities (mentioned and highlighted before), as well as problem-solving, however the teacher tries to be the last source of help. The teacher walks around to ensure everyone is doing right and makes effort to provide a wide spread optimist attitude toward the methods (Ellis, 2003).

In while-task, which is carried out in about 30 minutes, the students work within their teams to make sure that all team members had mastered the lesson thoroughly, because each team-mate is responsible for another's understanding. On the other hand, the roles in STAD and CIRC are not fixed and the team-mates do their best to reach to a correct agreement. Unlike individual learning, people engage in collaborative learning, capitalize on one another's resources and skills. They ask one another for information and monitor one another's ideas.

As it is planned, the participants of both mentioned experimental groups, are required to perform tasks in two different phases in post-task. The first phase can be interpreted as the control- phase, which aims to push students toward giving a summary of what they have learned. The role of multi-word units and complexities in learner's explanations is undeniable. The summary is explained by all participants, but each individual takes one part of the story and the other part is essentially given over another team-mate, following the last words said by the last member. In other words, the whole summary is done by all team-mates (Jeremy Harmer, 2015).

Carrying out these steps guide the group to a better production and a deep understanding, while students present a specific part of summary, other team-mates start to focus on what is said by the speaker for the purpose of giving suggestions. Some forms are distributed among students to make notes of the suggested multi-word units and complexities, which are worthsaying, but the speaker misses. Subsequently, the notes will be discussed to enhance the member's speaking complexity. This cyclic process occurs for all members. Following the controlled phase, the learners are asked to answer the questions posed and written by the teacher on the board. The students are provided with questions related to their personal experiences. This can be observed as freephase, which makes the opportunity of speaking in a more natural context. Furthermore, it makes the participants able to connect their knowledge to their prior experiences. In this phase, all the participants share and spread their ideas in identified groups and the teacher's monitoring as well as her contribution, is a beneficial supportive point. In all process of free-task, students add their suggested multi-word units as complexities, next to each team-mate's name on the given forms. The post-task as the most considerable part, continues for the remained one hour of per session. This stage is followed by a particular point, which is a friendly gathering of students in each team, discussing the written suggested complexities, one another's strenghts and weaknesses.

There is much common ground between the two methods, and all mentioned procedures in STAD and CIRC move the same until holding observing suggested complexities by all participants in each individual team, but they differ with an added stage in CIRC, as a similar collaborative short writing on the posed topic. CIRC continues peer learning along with writng a brief summary of what is discussed and making a prediction of the text given. It is made up by all participants on distributed papers. Although, the summary present the key points, the prediction includes learner's creative ideas as authors who co-write jointly and in collaborataion.

\section{RESULTS AND DISCUSSION}

The present study, aimed at comparing the differential effect of student team-achievement divisions, and cooperative integrated reading and composition, on EFL learners' speaking complexity.

\section{Data Analyses and Results}

The results of the piloting results, showed that the first draft of PET contained 100 items of reading, writing, listening and speaking. No item lacked suitable item facility, item discrimination or reliability. The reliability of writing and speaking parts were calculated using inter-rater reliability method (pearson correlation), and the reliability of the Reading and Listening Parts were computed via KR-21.

As displayed in table 4.1, the descriptive statistics, as represented in Table 4.1, exhibits that the mean, median and mode of the PET scores were 68.47, 69, and 63 respectively.

The researcher provided the related descriptive statistics before explaining the results of independent samples t-test

Table 4.1. Descriptive statistics for PET

\begin{tabular}{lcccccc}
\hline $\mathbf{N}$ & Mean & Median & Mode & SD & Skewness ratio & Kurtosis ratio \\
\hline 90 & 68.47 & 69.00 & 63 & 7.74 & -0.073 & -1.334 \\
\hline
\end{tabular}


on the posttest, the results of which are set forth in Table 4.2., The table exhibits the mean, standard deviation, and number of students for the STAD Group $(=2.92, S D=.34, n=30)$, and CIRC Group $(=3.23, S D=.34, n=30)$. The number of complexities in 100 words, was the used measurement for speaking complexity (Richards, 2008).

It is noteworthy that the minimum and maximum scores of speaking complexity in STAD group were 2.08 and 3.60 respectively, whereas in CIRC the mentioned items were 2.51 and 3.75. Additionally the assumption of normality of the speaking complexity scores was checked via the ratios of skewness and kurtosis.

The independent samples t-test (Table 4.3) found a statistically significant difference $(t(59)=3.11, p=.003, p$ $<.05)$ in speaking complexity measures between the STAD and CIRC Groups on the benefit of the CIRC Group. Accordingly, the null hypothesis of the study that says, "There is no significant difference between the effect of learners' Team-Achievement Divisions and Cooperative Integrated Reading and Composition on EFL learners' speaking complexity" was rejected. Therefore, it is claimed that there is a significant difference between the effect of learners' Team-Achievement Divisions and Cooperative Integrated Reading and Composition on EFL learners' speaking complexity. In fact, it was discovered that Cooperative Integrated Reading and Composition was more effective than learners' Team-Achievement Divisions to enhance speaking complexity of EFL learners.

\section{DISCUSSION}

As the analyses indicates, there is a significant difference between the posttest scores of the two experimental groups and the speaking complexity scores, means, minimum, and maximum scores for the CIRC Group are noticeably higher than the STAD Group regarding the posttest of speaking complexity. The obtained results of the present study using the two collaborative scores can be supported by the noticable collaboration of complexity note taking before speaking as is followed in CIRC procedures. As it is proved by Lyubomirsky(2000) a positive effect for allowing notetaking and working on them by making use of different learning techniques (story making, retelling, summarizing,..) is found.

Table 4.2. Descriptive statistics of two group's speaking complexity scores

\begin{tabular}{lcccc}
\hline Group & N & Mean & SD & $\begin{array}{c}\text { Standard error } \\
\text { mean }\end{array}$ \\
\hline STAD & 30 & 2.917 & 0.440 & 0.079 \\
CIRC & 30 & 3.232 & 0.342 & 0.062 \\
\hline
\end{tabular}

This is seen as paper-and-pencil learning, which can be considered as an interaction between writing and speaking.

Speaking complexity has been proved to be one of the most challenging aspects of English for learners of English either as a foreign language (EFL) or as a second language (ESL), yet highly productive and widely used by native speakers.

However, the question, as to the best method of teaching complexities remains under-researched or unresolved. What scholars have contributed to this area of research, is the finding that its teaching must not be taken for granted. Furthermore, other researchers such as Tang(2013), concluded that teaching complexities with lexical approach can effectively enhance students' learning. CIRC is in theory, more suitable for achieving the desired outcomes and, in practice, it proved to be more contributory and conducive to the acquisition of speaking comlexity compared to STAD. (Rimani Nikou, et al, 2014). In the end, A large number of educational problems can be solved through various approaches of cooperative learning. Johnson and Johnson (1999) describes CIRC as "one of the strongest areas of principle, research, and practice in teaching" (p. 5). Also, the results of Zarei's (2012) findings show that CIRC leads to a better result than STAD in vocabulary learning of elementary learners.

\section{CONCLUSION}

Speaking complexity, is a popular research target and has been used as a contribution in many fields toward achieving the ability of natural communication. Although, it is commonly thought that language proficiency is only defined by accuracy and fluency, the characteristics of natural discourse take a vital role. The contribution of native speakers' speaking complexities to the development of speaking naturalness was the main target of the present research study which was seen by implementing two cooperative methods as STAD and CIRC.This study was aimed to investigate the contribution of two cooperative methods as STAD and CIRC to the development of Iranian intermediate EFL learners' speaking complexity. In the mean time, the mean scores of the two raised cooperative methods, obtained by the participants, were compared after receiving the 10 -session treatment. The results of the study show the effectiveness of Cooperative Integrated Reading and Composition method, on enhancement of Speaking Complexity.

The findings of the present research study, would be seen as a great interest area for language teachers, who wish to persuade language learners to near-native speaking ability by appropriate utilization of Speaking Complexities and build a teamwork atmosphere in classroom contexts.

Table 4.3. Independent samples test for two groups' speaking complexity (Posttest)

\begin{tabular}{|c|c|c|c|c|c|c|}
\hline \multicolumn{3}{|l|}{ Levene's test for variances } & \multicolumn{4}{|c|}{ T-test for means } \\
\hline Factor & $\mathbf{F}$ & Sig. & $\mathbf{t}$ & df & Sig. (2-tailed) & Mean difference \\
\hline Equal variances assumed & 2.518 & 0.118 & 3.113 & 59 & 0.003 & 0.315 \\
\hline Equal variances not assumed & & & 3.126 & 56.403 & 0.003 & 0.315 \\
\hline
\end{tabular}




\section{REFERENCES}

Adesoji, F. A., \& Ibraheem, T. L. (2009). Effects of student team-achievement divisions strategy and mathematics knowledge on learning outcomes in chemical kinematics. Journal of International Social Research, 2(6), 15-25.

Arends, R. I. (1997). Classroom instruction and management. New York: The McGraw-Hill Companies, Inc.

Brown, H. D. (2001). Teaching by principles: An interactive approach to language pedagogy. White Plains,NY: Longman. Cambridge: Cambridge University Press.

Durukan, E. (2010). Effects of Cooperative Integrated Reading and Composition technique on Reading-Writing skills. Academic Journal, 6(1), 102-109.

Ellis, R. (2003). Task-based Language Learning and Teaching. Oxford University Press.

Feichtner, S. B., \& Davis, E. A. (1991). Why some groups fail: A survey of students' experiences with learning groups. The Organizational Behavior Teaching Review, 9(4), 75-88.

Jeremy Harmer.(2015). The practice of English Language Teaching: Pearson.

Johnson, D. W., \& Johnson, R. T. (1999). Learning together and alone: Cooperative, competitive, and individualistic learning ( $5^{\text {th }}$ ed.). Boston, MA: Allyn\& Bacon.

Johnson, D. W., \& Johnson, R. T. (1999). Learning together and alone: Cooperative, competitive, and individualistic learning ( $5^{\text {th }}$ ed.). Boston, MA: Allyn\& Bacon.

Johnson, D. W., Johnson, R. T., \& Smith, K. A. (1991). Active learning: Cooperation in the college classroom. Edina, MN: Interaction Book Company.

Johnson, R. T., \& Johnson, D. W. (1985). Relationships between black and white students in intergroup cooperation and competition. The Journal of Social Psychology, 125(4), 421-428.

Kagan, S. (1986). Cooperative learning and sociological factor in schooling in Beyond language: Social and cultural factors in schooling language minority students. Los Angeles, CA: California State University Evaluation, Dissemination and Assessment Center.

Kagan, S. (1994). Cooperative learning. San Juan Capistrano, CA: Kagan Cooperative learning.

Khan, G. N., \& Inamullah, H. M. (2011). Effects of students team achievement division (STAD) on academic achievement of studies. Asian Social Science, 7(12), 211-215. http://dx.doi.org/10.5539/ass.v7n12p211

Killen, R (2007). Effective Teaching Strategies for OBE Teaching. $2^{\text {nd }}$ Edition. Boston: Social science press.

O'keeffe, A., McCarthy, M., \& Carter, R. (2007). From corpus to classroom: Language use and language teaching. Cambridge University Press.
Pawley, A., \& Syder, F. H. (1983). Two puzzles for linguistic theory: Nativelike selection and nativelike fluency. Language and communication, 191, 225.

Putnam, R. (1995). Bowling alone: America's declining social capital. Journal of Democracy, 6(1), 65-78.

Rashidi, N, \& Najafi, R. (2010). A study of the representation of Culture in Iran Language Institute Advanced Level Textbooks.

Richards, J., \& Renandya, W. (2002). Methodology in Language Teaching: An Anthology of Current Practice. Cambridge: Cambridge University Press.

Richards, J., \& Rodgers, T. (1986). Approaches and methods in language teaching ( $2^{\text {nd }}$ ed.). Cambridge: Cambridge University Press.

Richards, J.C. (2008). Moving Beyond the plateau. From intermediate to advanced levels in language learning. Cambridge: Cambridge University Press.

Rimani Nikou, F., Bonyadi, A., \& Ebrahimi, K. (2014). The effect of student team-achievement division (STAD) on language achievement of Iranian EFL students across gender. European Online Journal of Natural and Social Sciences 3(4), 936-949.

Sharan, Y. (2014). Learning to cooperate for cooperative learning. Anales De Psicologia, 30(3), 802-807.

Slavin, R. E. (1980). Cooperative learning. Review of Educational Research, 50(2), 315-342.

Slavin, R. E. (1994). Using student team learning ( $2^{\text {nd }}$ ed.). Baltimore, MD: Johns Hopkins University, Center for Social Organization of Schools.

Slavin, R.E (2010). Co-operative Learning What Makes Group work. In Dumont H, Istance D, and Benavides F (Eds.), The Nature of Learning Using Research to Inspire Practice. (pp. 161-178). Paris, France OECD.

Tang, J. (2013). Input of chunks and its effects on L2 Learners'listening competency. Theories and practice in language studies, 3(7), 1264-1269.

Tiantong, M., \& Teemuangsai, S. (2013). Student team achievement divisions (STAD) technique through the moodle to enhance learning achievement. International Education Studies, 6(4), 85-92.

Tran, V. D. (2014). The Effects of Cooperative Learning on Academic Achievement and Knowledge Retension. International Journal of Higher Education, 3(2), 131-140

Wray, A. (2002). Formulaic language in computer-supported communication: Theory meets reality. Language Awareness, 11(2), 114-131.

Zarei, A. (2012). The Effects of STAD and CIRC on L2 Reading Comprehension and Vocabulary Learning. Frontiers of Language and Teaching, 3(2), 161-173. 